\title{
不飽和砂の浸潤・締固め特性と 加振時破壊形態に関する実験的考察
}

\author{
藤森 弘晃 ${ }^{1}$. 荒木 功平 ${ }^{2}$ \\ 1 学生会員 山梨大学大学院 医学工学総合教育部（广400-8511 山梨県甲府市武田 4-3-11） \\ E-mail: g15mc006@yamanashi.ac.jp \\ 2 正会員 山梨大学大学院助教 総合研究部（干400-8511 山梨県甲府市武田 4-3-11） \\ E-mail: karaki@yamanashi.ac.jp
}

\begin{abstract}
近年，地下水位が深い位置にある不飽和埋め戻し地盤において，飽和地盤の挙動とは異なる沈下が生じ， 度々報告されている。地震動による不飽和地盤の沈下に関しては研究・報告が少なく, メカニズムも解明 されていない. 本研究では不飽和状態の模型地盤を作製し, 振動台を用いて加速度を与え, 加振前と加振 後の沈下量, 飽和度, 乾燥密度の関係を求めている. その結果, 不飽和地盤の破壊形態にクラックが生じ るケースと地表面に流出水が生じるケースを確認した。 そして，二つの破壊形態が分かれる条件について， 境界值となる飽和度の存在を示唆している. 加えてその飽和度は締固め試験や水平浸潤試験から導かれる 飽和度と近い值を示すことを考察している。
\end{abstract}

Key Words: unsaturated soils, degree of saturation, settlement, permeability, compaction characteristic

\section{1. はじめに}

近年，地下水位が深い位置にある不飽和埋め戻し地盤 において，飽和地盤の挙動と異なる地震動に伴う沈下現 象が生じ，度々報告・指摘され始めている．新潟県中越 沖地震（2007 年 7 月 16 日）が発生した際には, 繰返し せん断により柏崎㺫羽原子力発電所敷地内で埋め戻し不 飽和土が 40〜80 cm 沈下していることが確認された ${ }^{1)}$. 原子炉建屋は支持岩盤に直接設置されているため沈下を 起こさなかったが，周辺地盤の沈下により，各種埋設配 管が寸断された ${ }^{2}$. また，東北地方太平洋沖地震（2011 年 3 月 11 日）では，宮城県内の谷地形に盛られた厚い 埋め戻し土により造成された盛土（不飽和谷埋め盛土） 上の住宅地において最大 $35 \mathrm{~cm}$ の摇すり込多沈下が発生 し，大きく注目された ${ }^{3)}$.

近年の大規模な地震災害を受け，不飽和地盤の破壊形 態が飽和地盤の破壊形態と全く異なる挙動を示すことが わかり，無視できなくなったため，飽和地盤の評価法に よらない不飽和地盤を対象とした評価法の確立が急務と なっている ${ }^{4)}$ なしかしながら，不飽和地盤は飽和地盤に 比べ強度が大きく安全であると考えられてきたため，依 然として地震動に伴う不飽和地盤の沈下現象や破壊形態 のメカニズムに関する研究報告は極めて少ない 5),6.

本研究では地震動による不飽和地盤の沈下挙動・破壊
形態のメカニズム解明を目指し，振動台を用いて実験的 に研究している. 具体的には, 初期飽和度と初期乾燥密 度をそれぞれ設定した不飽和土（茨城県鹿島港付近で採 取した鹿島海浜砂）からなる模型地盤を作製し，振動台 を用いて加振し, 加振後の沈下量, 飽和度, 乾燥密度の 関係を把握している。一方，用いた試料の水平浸潤特性， 締固め特性，保水特性を明らかにし，不飽和地盤の特徵 的な破壊形態との関連性を考察している.

\section{2. 用いた試料（鹿島海浜砂）の物理特性, 締固 め特性，浸潤特性，保水特性}

本実験では茨城県鹿島港付近で採取した鹿島海浜砂を 用いた．鹿島海浜砂の物理特性を把握するため，土粒子 の密度試験（JIS A 1202），土の粒度試験（JIS A 1204）， 砂の最小密度・最大密度試験（JIS A 1224）, 突固めに よる土の締固め試験（JIS A 1202，A-a 法）を行った.

表-1 に種々の土質試験から得られた鹿島海浜砂の基本 的物理特性についてまとめている，概ね豊浦砂の物理特 性 ${ }^{7}$ に近いことがわかる. 土粒子の密度 $\rho_{\mathrm{s}}=2.676 \mathrm{Mg} / \mathrm{m}^{3}$ は一般的な無機質の鉱物の密度 $2.5 \sim 2.8 \mathrm{Mg} / \mathrm{m}^{3}$ の範囲内 である ${ }^{8)}$. 最大間隙比 $e_{\max }$, 最小間隙比 $e_{\mathrm{min}}$, 平均粒径 $D_{50}$ は概ね豊浦標準砂と同じ值を示した。 
表-1 鹿島海浜砂の物理特性

\begin{tabular}{|c|c|c|c|}
\hline 土粒子の密度 & $\rho_{\mathrm{s}}$ & $\left(\mathrm{Mg} / \mathrm{m}^{3}\right)$ & 2.676 \\
\hline 最大間隙比 & $e_{\max }$ & - & 1.082 \\
\hline 最小間隙比 & $e_{\min }$ & - & 0.652 \\
\hline 均等係数 & $U_{\mathrm{c}}$ & - & 1.864 \\
\hline 曲率係数 & $U_{\mathrm{c}}{ }^{\prime}$ & - & 0.867 \\
\hline 平均粒径 & $D_{50}$ & $(\mathrm{~mm})$ & 0.200 \\
\hline 最大乾燥密度 & $\rho_{\mathrm{dmax}}$ & $\left(\mathrm{Mg} / \mathrm{m}^{3}\right)$ & 1.634 \\
\hline 最適含水比 & $w_{\mathrm{opt}}$ & $(\%)$ & 15.8 \\
\hline
\end{tabular}

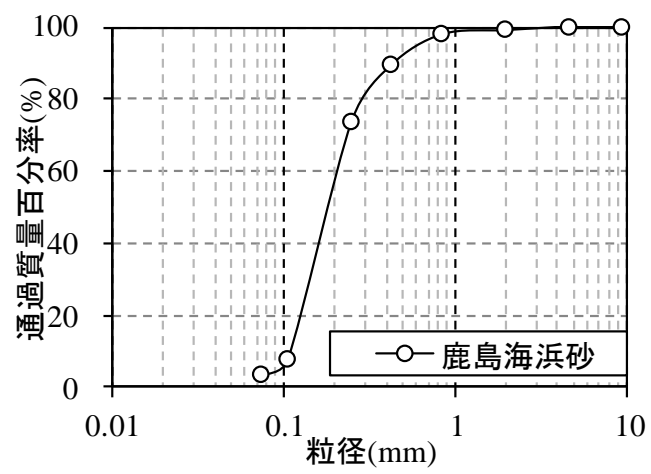

図-1＼cjkstart粒径加積曲線

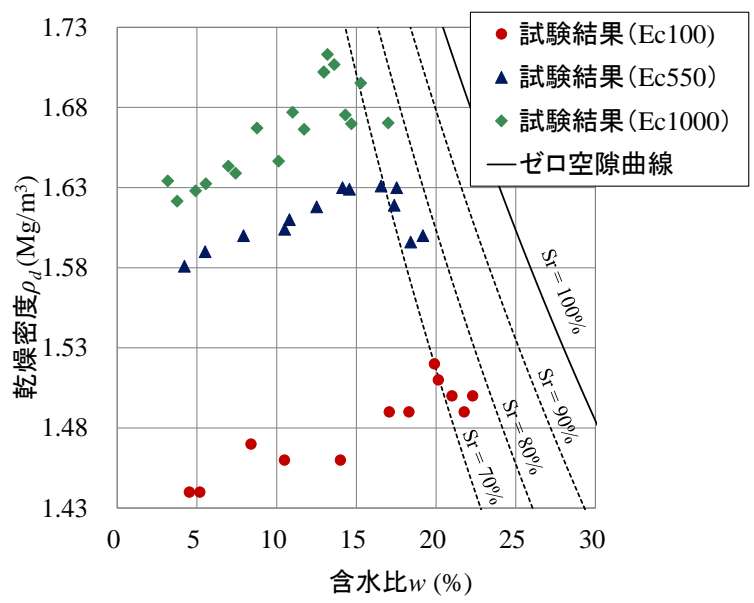

図-2 締固め曲線

図-1 に鹿島海浜砂の粒径加積曲線を示す．均等係数 $U_{\mathrm{c}}=1.864$, 曲率係数 $U_{\mathrm{c}}^{\prime}=0.867$ を得た. この結果から 鹿島海浜砂は分級された粒径幅の広くない砂であるとい える.

図-2 に突固めによる締固め試験を締固めエネルギー の 3 種類 $\left(E_{\mathrm{c}}=100,550,1000 \mathrm{~kJ} / \mathrm{m}^{3}\right)$ で行った試験結果 （乾燥密度～含水比関係）を示す. 締固めエネルギー $E_{\mathrm{c}}=550\left(\mathrm{~kJ} / \mathrm{m}^{3}\right) \quad$ の試験結果から最大乾燥密度 $\rho_{\mathrm{dmax}}=$ $1.634 \mathrm{Mg} / \mathrm{m}^{3}$, 最適含水比 $w=15.8 \%$ を得た. また, この 時飽和度 $S_{\mathrm{r}}=66.3 \%$ である. 図-2に示すように, 締固め 曲線はいずれの締固めエネルギーでも飽和度 $80 \%$ 超え ることはなかった。 これは，外的エネルギーによる排水 が伴うと, 飽和度は $80 \%$ 程度に落ち着くことを示してい ると考えられる.

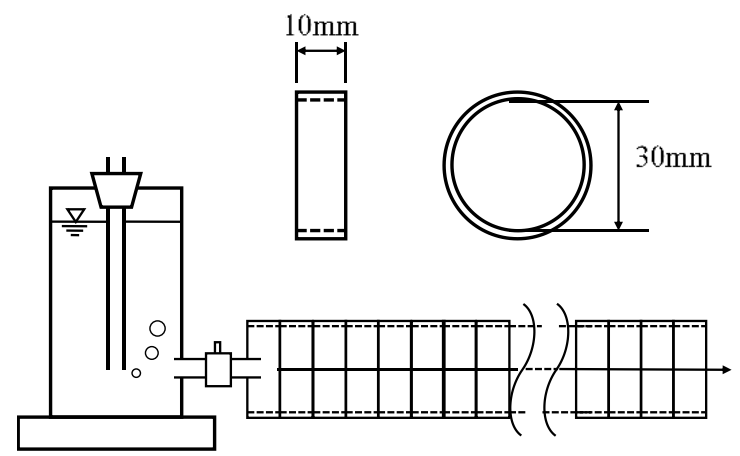

図-3 水平浸潤試験装置の模式図

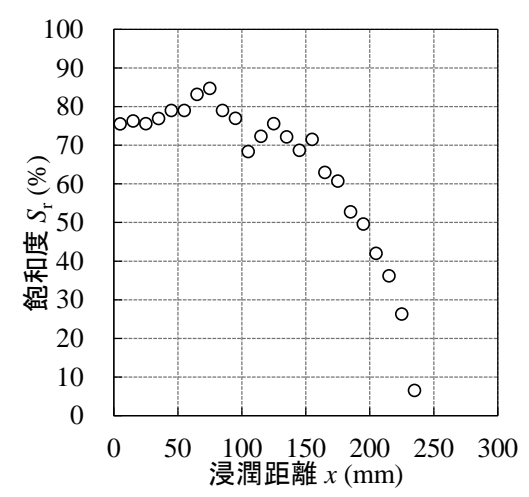

図-4 飽和度～浸潤距離関係

重力の作用を考えず，土の吸水力による飽和度変化を みるため給水水頭 $0 \mathrm{~mm}$ で水平浸潤試験 ${ }^{9}$ をを行った.

図-3 に水平浸潤試験装置模式図を示す，幅 $10 \mathrm{~mm}, 内$ 径 30mm のリングセル 50 個（全長 $500 \mathrm{~mm}$ ） から成る透 明なアクリル製試料円筒およびマリオット管式給水装置 からなるが水頭差は与えない! 給水開始後, 浸潤前線を 目視で確認し，所定の位置（本論文では全長の約半分の $250 \mathrm{~mm}$ を目安とした）に達したら給水を止め，時間を 計測する. その後ただちに分解し, セル毎に給水面から の距離〜含水比関係を把握する.

図-4に得られた飽和度〜浸潤距離関係（乾燥密度 $\rho \mathrm{d} 0$ $\left.\fallingdotseq 1.60 \mathrm{Mg} / \mathrm{m}^{3}\right)$ を示す。浸潤時間は 2244 秒であった。浸 潤距離 0〜150mm ではバラツキはあるが，概ね $80 \%$ 程度 であることがわかる．このことから，給水水頭が $0 \mathrm{~mm}$

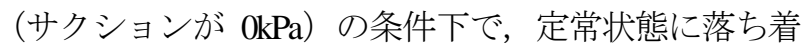
いた際，飽和度は $80 \%$ 程度を示すと考えられる.

図-5(a)，(b)に豊浦砂と鹿島海浜砂の排水過程における 水分特性曲線をそれぞれ示す（乾燥密度，相対密度も図 示する）。水分特性曲線は水分特性曲線測定装置

(UMS 社製 HYPROP) を用い，突固めて作製した供試 体をあらかじめ脱気水で飽和させ，蒸発法（排水過程） により試料のサクションと質量を経時的に測定し求めた. 図-5(a)から本装置と神谷ら ${ }^{10)}$ の水分特性曲線は良好な関 係を示し, 測定值は妥当と考えている. 飽和度の高い領 域で多少異なるが，これは密度差の影響と考えている。 


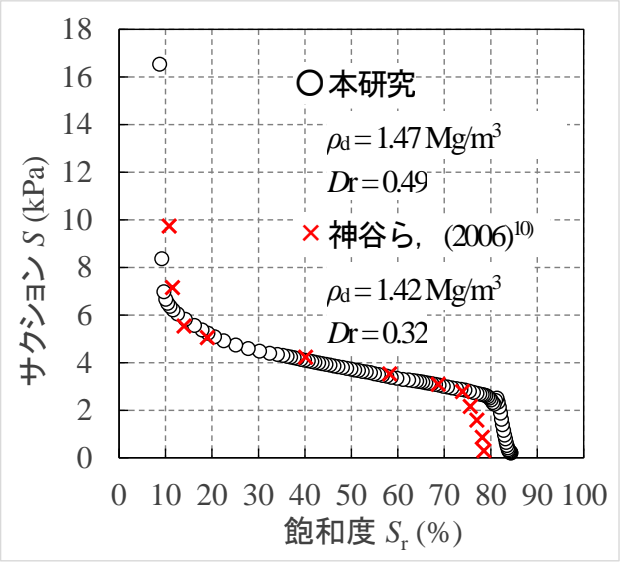

(a) 豊浦砂



(b) 鹿島海浜砂

図-5 水分特性曲線

図-5(b)より，鹿島海浜砂の空気侵入值はともに飽和度 $85 \%$ 前後と考える. 飽和度 $S_{\mathrm{r}}=85 \%$ を超えるとサクショ ンの急激な低下が見られ，サクション $S=0 \mathrm{kPa}$ のさ， 飽和度 $S_{\mathrm{r}}=90 \%$ 程度であることがわかる. 飽和度 $S_{\mathrm{r}}=$ 80\%から 10\%まではサクションは概ね $S=3 \mathrm{kPa}$ から $20 \mathrm{kPa}$ であり大きな変化が見られないが，飽和度 $S_{\mathrm{r}}=10 \%$ 未満 では急激なサクションの変化がみられた。

\section{3. 振動台を用いた不飽和地盤の模型実験概要}

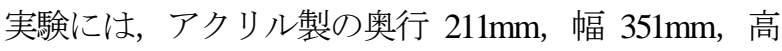
さ $260 \mathrm{~mm}$, 総体積 $1.0 \times 107 \mathrm{~mm}^{3}$ の土槽（以下，小型土槽） と，アクリル製の奥行 $200 \mathrm{~mm}$ ，幅 $950 \mathrm{~mm}$ ，高さ $550 \mathrm{~mm}$, 総体積 $7.6 \times 107 \mathrm{~mm}^{3}$ の土槽（以下，大型土槽）の 2 種類 を用いた。 供試体の初期高さは小型土槽で $135 \mathrm{~mm}$ ，大 型土槽で $400 \mathrm{~mm}$ に設定した. ここで，模型地盤は密度 にバラツキが生じないように乾燥密度が均一になるよう 留意して 5 層に分け 1 層ずつ転圧して作製した。

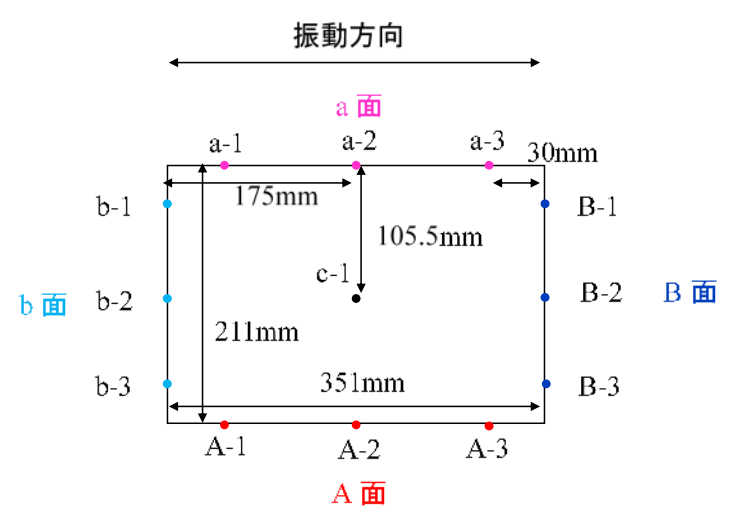

(a) 小型土槽

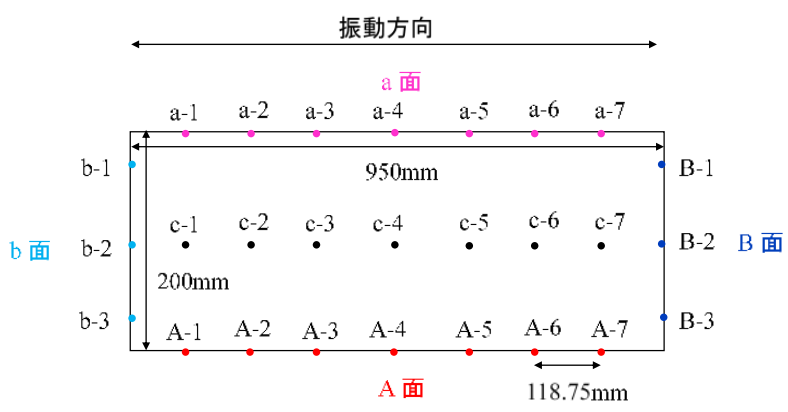

(b) 大型土槽

図-6 模型土槽の上面図

最初に，作製する試料の乾燥密度と飽和度を設定し， そこから乾燥砂の質量, 水の質量をそれぞれ計算した. 乾燥砂と水をよく混合し，混合した試料を 5 等分して模 型土槽に入れながら転圧し締固めを行った.

振動は正弦波で与え，振動数一定 $(5 \mathrm{~Hz})$ と振幅一定 (10mm) の 2 パターンで行った. 100Gal ずつ加速度を 増やし 1 分間加振し, 同様の作業を行い, 200Gal から $700 \mathrm{Gal}$ まで飽和度〜沈下量〜加速度関係を求める. なお, 実際の地震動は種々のパラメータにより特徴づけられる が，本振動台実験では，昨今計測されている強震動のお およそ平均的な加速度レベルであると考えられる 200 $700 \mathrm{Gal}$ で加振した ${ }^{11)}$ (新潟県中越沖地震（2007年）では 最大 $701.0 \mathrm{Gal}$ ，長野県北部の地震（2011 年）では最大 $207.2 \mathrm{Gal}$, 東北地方太平洋沖地震（2011 年）では最大 1076.4 Gal が観測されている）.

図-6(a)，(b)に小型土槽と大型土槽それぞれの沈下量の 測定点を示す. 図-6(a), (b)に示す A 面, a 面と平行に (B 面や $\mathrm{b}$ 面に直交方向) 1 分間の加振後, 沈下量を鋼 製定規により各点計測した. 加振による地盤の沈下はバ ラツキがあるため, 測定点全点の平均沈下量で評価を行 う。ただし，クラックが生じた場合は，クラック内では 測定せず，クラック縁の地表面で計測した. 


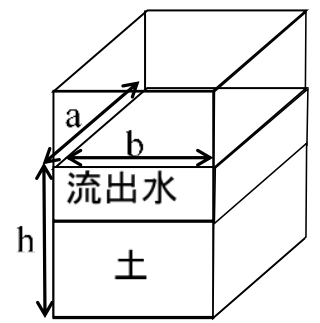

図-7 液状化後の測定方法

表-2 鹿島海浜砂の物理特性

(a) 小型土槽

\begin{tabular}{|c|c|c|c|c|c|c|}
\hline & Name & $\begin{array}{c}\rho_{\mathrm{d} 0} \\
\left(\mathrm{Mg} / \mathrm{m}^{3}\right)\end{array}$ & $\begin{array}{l}S_{\mathrm{r} 0} \\
(\%)\end{array}$ & Name & $\begin{array}{c}\rho_{\mathrm{d} 0} \\
\left(\mathrm{Mg} / \mathrm{m}^{3}\right)\end{array}$ & $\begin{array}{l}S_{\mathrm{r} 0} \\
(\%)\end{array}$ \\
\hline \multirow{9}{*}{ 小型 } & case 1 & 1.15 & 40 & case 10 & 1.25 & 40 \\
\hline & case 2 & 1.15 & 45 & case11 & 1.25 & 50 \\
\hline & case3 & 1.20 & 25 & case 12 & 1.25 & 55 \\
\hline & case 4 & 1.20 & 30 & case 13 & 1.30 & 35 \\
\hline & case5 & 1.20 & 40 & case 14 & 1.30 & 40 \\
\hline & case6 & 1.20 & 45 & case 15 & 1.30 & 55 \\
\hline & case7 & 1.20 & 50 & case 16 & 1.30 & 60 \\
\hline & case8 & 1.25 & 30 & case 17 & 1.35 & 60 \\
\hline & case9 & 1.25 & 35 & case 18 & 1.35 & 65 \\
\hline
\end{tabular}

(b) 大型土槽

\begin{tabular}{|l|l|r|r|}
\hline & Name & $\begin{array}{r}\rho_{\mathrm{d} 0} \\
\left(\mathrm{Mg} / \mathrm{m}^{3}\right)\end{array}$ & $\begin{array}{r}S_{\mathrm{r} 0} \\
(\%)\end{array}$ \\
\hline \multirow{4}{*}{ 大型 } & case1' & 1.25 & 40 \\
\cline { 2 - 4 } & case2' & 1.20 & 40 \\
\cline { 2 - 4 } & case3' & 1.25 & 50 \\
\cline { 2 - 4 } & case4' & 1.25 & 30 \\
\cline { 2 - 4 } & case5' & 1.15 & 40 \\
\cline { 2 - 4 } & case6' & 1.30 & 60 \\
\cline { 2 - 4 } & case7' & 1.35 & 60 \\
\hline
\end{tabular}

図-7 に加振後の飽和度の算出方法を示す．加振後に 底面から流出水表面までの高さ $h$ を計測し模型土槽の長 辺 $a$ 短辺 $b$ から体積を求め水面以下の飽和度を算出した.

表-2(a)，(b)に本論文で行っている小型土槽と大型土槽 の実験ケースを示す．初期飽和度，初期乾燥密度を変え て 25 ケース行っている. 表-2(a), (b)より，初期乾燥密 度は全て図-2 の締固め曲線から得られた各最大乾燥密 度より小さい值である。

\section{4. 加振時の不飽和地盤挙動の実験結果と考察}

本章では加振前および加振後の飽和度変化に着目する。 ただし，地表面（または水面）以下の土槽全体の飽和度 について着目している.

\section{(1) 地震動に伴う破壊形態の違い}

200～700gal 加振後の破壊形態は大きく 2つに分けられ 地表面に流出水を生じたケース（以下，不飽和液状化と 称す），地表面にクラックやすべりを生じたケース（以

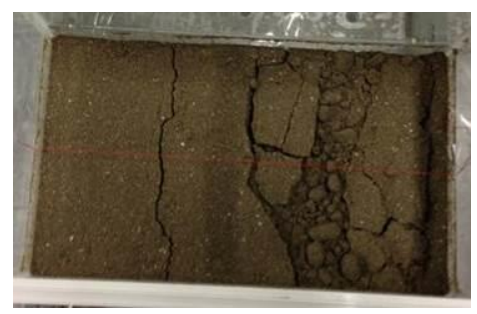

(a) 不飽和クラック

$\left(S_{10}=55 \%, \quad a_{\mathrm{f}}=700 \mathrm{Gal}, \quad S_{\mathrm{ff}}=71.7 \%\right)$

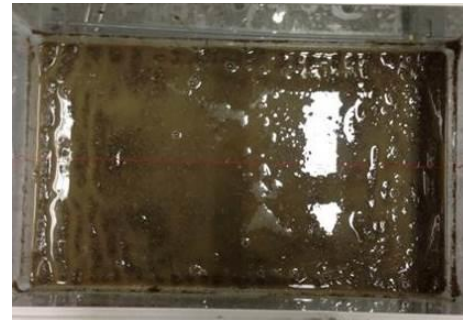

(b) 不飽和液状化

$\left(S_{10}=60 \%, \quad a_{\mathrm{f}}=700 \mathrm{Gal}, \quad S_{\mathrm{ff}}=82.5 \%\right)$

写真-1 小型土槽 $\left(\rho_{\mathrm{d} 0}=1.30 \mathrm{Mg} / \mathrm{m}^{3}\right)$

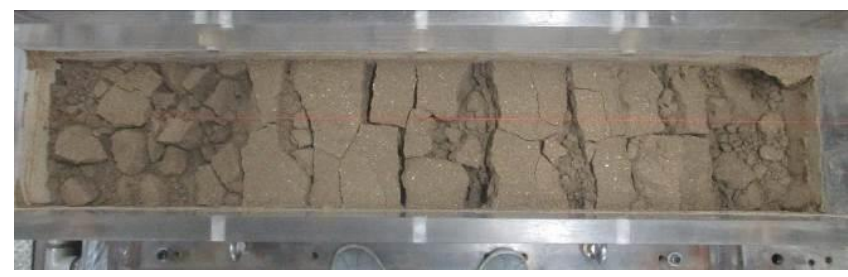

(a) 不飽和クラック

$\left(a_{\mathrm{f}}=500 \mathrm{Gal}, \quad S_{\mathrm{ff}}=79.8 \%\right)$

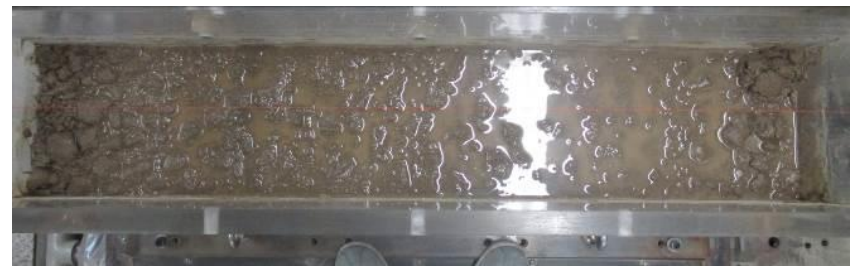

(b) 不飽和液状化

$\left(a_{\mathrm{f}}=600 \mathrm{Gal}, \quad S_{\mathrm{ff}}=81.7 \%\right)$

写真-2 大型土槽 $\left(S_{10}=60 \%, \rho_{\mathrm{d} 0}=1.5 \mathrm{Mg} / \mathrm{m}^{3}\right)$

下，不飽和クラックと称す）があった．写真-1(a)，(b)に 小型土槽における不飽和クラック, 不飽和液状化, 写真 -2(a), (b)に大型土槽における不飽和クラック，不飽和液 状化をそれぞれ示す。

写真-1(b)に示すように，不飽和液状化が発生した地盤 の表面には泡の発生がみられた。これは，先に地表面付 近が飽和に近づくので間隙空気の排出が泡として見える と考えられる. また, 写真-1(a)と(b)のケースでは初期飽 和度に 5\%の違いしかないが，不飽和地盤の加振後の破 壊形態は大きく異なることがわかる．初期飽和度のわず 
かな違いが不飽和地盤に全く異なる破壊形態をもたらす ことを示している．なお，写真-1(a)および(b)の加振後の 飽和度 $S_{\mathrm{ff}}$ はそれぞれ $71.7 \% ， 82.5 \%$ であった。

写真-1(a) と(b)から，与えられた地震動が同じでも，初 期飽和度が $5 \%$ 程度異なっていれば，全く異なる破壊形 態を示すことがわかる.

写真-2(a)，(b)は， $S_{\mathrm{i} 0}=60 \%, \quad \rho_{\mathrm{i} 0}=1.35 \mathrm{Mg} / \mathrm{m}^{3}$ で行った 実験での $500 \mathrm{Gal}$ 終了時と $600 \mathrm{Gal}$ 終了時をそれぞれ示し ている.

写真-2(a)は不飽和クラックが発生している. 中央部で はクラックが確認でき，振動方向に直交する面付近で大 きく沈下が発生している. 写真-2(b)では不飽和液状化が 発生している. 写真-2(a)の $500 \mathrm{Gal}$ 終了時の飽和度 $S_{\mathrm{fr}}$ は $79.8 \%$, 写真-2(b)の $600 \mathrm{Gal}$ 終了時の飽和度は $81.7 \%$ で った. 写真-2(a) と写真-2(b)では全く異なる破壊形態を示 しているが，加振後の不飽和地盤の飽和度にはわずかな 違いしかなかった。

写真-1(b), 写真-2(b)のように地表面より上に水面が表 れた状態であっても水面以深の全体の飽和度は約 $80 \%$ で あった. 地表面には目に見える状態で泡が確認できた. ここで, 地表面から水面までの流出水の飽和度が 80〜 100\%と考えると，地表面以深の飽和度は $80 \%$ 以下でな ければならない，いずれにしても地表面以深には空気が トラップされていると考えられる.

不飽和液状化を示した写真-1(b) と写真-2(b) で模型高さ は 2 倍以上異なる. しかし, 全体の飽和度はそれぞれ 82.5\%，81.7\%で大きな差はみられなかった.このことか ら, 不飽和液状化後の深度方向の飽和度分布には大きな 差は無いと考えられる.

図-8 は，本論文で行っている小型土槽を用いて行っ た全実験ケースをプロットしたグラフである. ×印のプ ロットは $700 \mathrm{Gal}$ 加振後に地盤にクラックやすべりが発 生したケース（不飽和クラック）であり， ○印でプロッ トしたケースは $700 \mathrm{Gal}$ 加振後に地表面に流出水を確認 したケース（不飽和液状化）である.

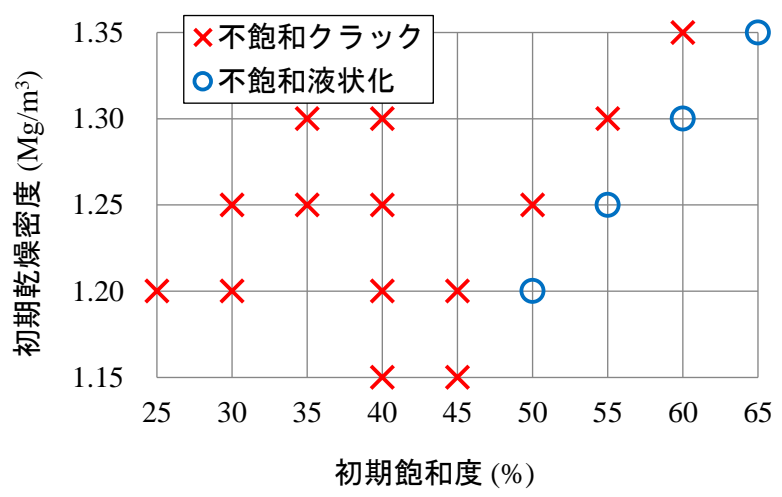

図-8 破壊形態の分かれる境界
図-8 より，不飽和クラックと不飽和液状化それぞれ の破壊形態を示した初期条件は概ね直線上にあることも 確認できる．ここで，×印のプロットを結んだ線を不飽 和クラックライン，○印のプロットを結んだ線を不飽和 液状化ラインと称する. 不飽和地盤の破壞形態が不飽和 クラックと不飽和液状化に分かれる不飽和クラックライ ンと不飽和液状化ラインの初期飽和度の差は 5\%しかな い.つまり, 不飽和地盤の初期飽和度が $5 \%$ 異なるだけ でそれぞれ全く異なる破壊形態をもたらすことがわかる。

\section{（2）地震動に伴う沈下挙動}

図-9(a) (e)に，それぞれ小型土槽を用いて初期乾燥密 度 $\rho_{\mathrm{d} 0}=1.15,1.20,1.25,1.30,1.35 \mathrm{Mg} / \mathrm{m}^{3}$ において, 初 期飽和度 $S_{10}$ を変化させた場合の平均沈下量〜加速度関 係を示す.

図-9(a)〜(e)より, 初期飽和度が大きいほど沈下量は増 大傾向にあることがわかる，また，初期飽和度が大きい ほど加速度の小さい段階で沈下を開始することがわかる. 平均沈下量は, 加速度が大きくなるほど大きくなり, $100 \mathrm{Gal}$ 増加に伴う沈下量の増え方も初期飽和度が大き いほど大きくなることがわかる.
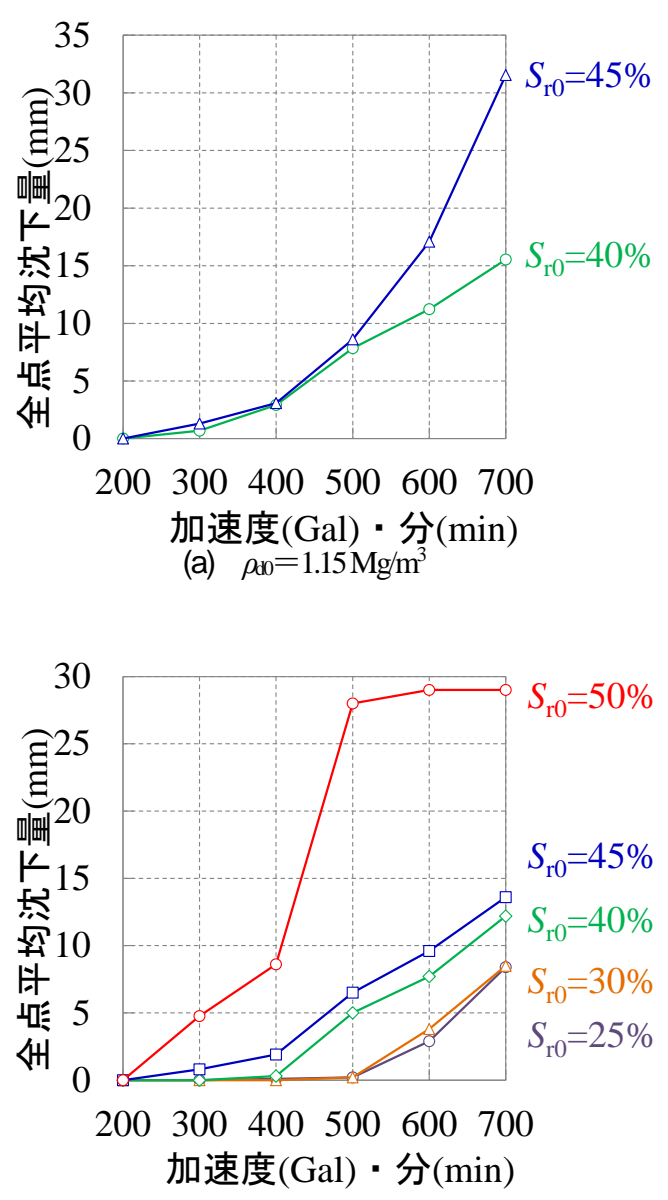

(b) $\rho_{\mathrm{ob}}=1.20 \mathrm{Mg} / \mathrm{m}^{3}$

図-9 加振時の沈下量～加速度関係（初期乾燥密度一定） 


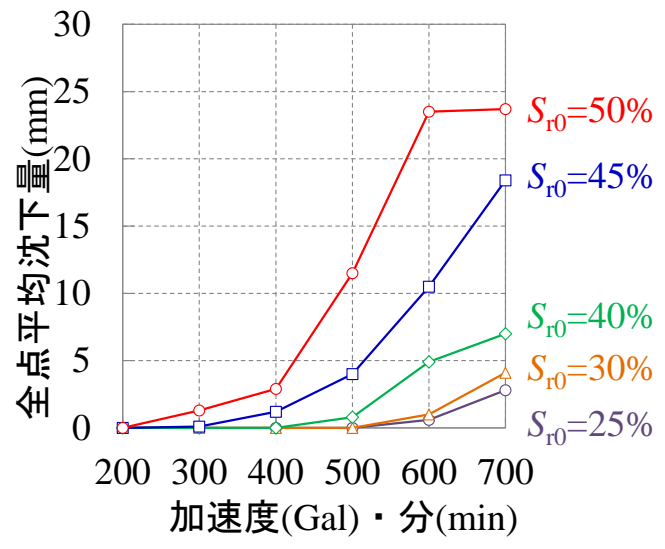

(c) $\rho_{\mathrm{o} 0}=1.25 \mathrm{Mg} / \mathrm{m}^{3}$

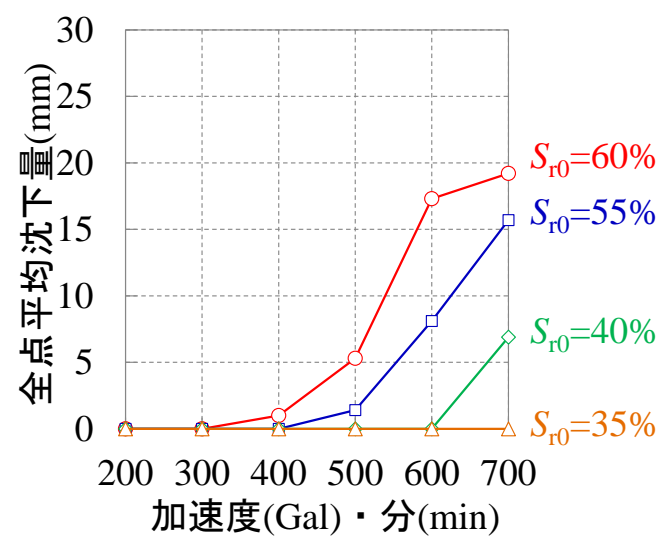

(d) $\rho_{\mathrm{d} 0}=1.30 \mathrm{Mg} / \mathrm{m}^{3}$

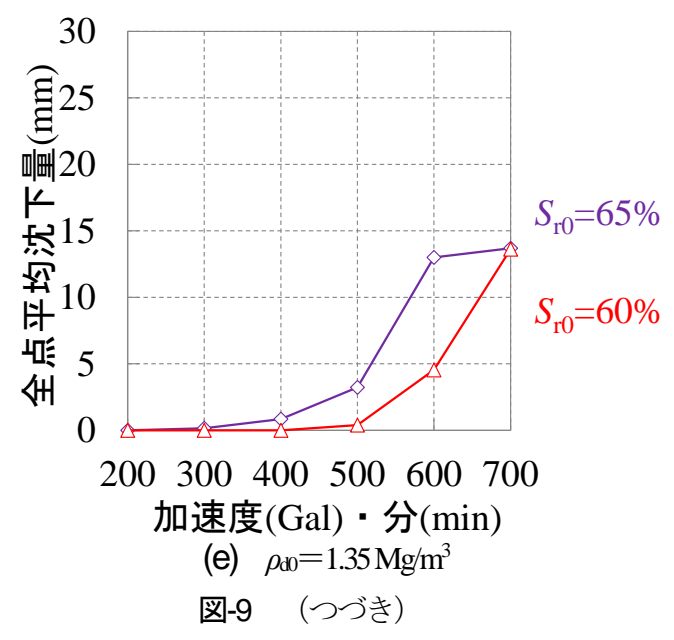

（3）地震動に伴う飽和度の変化

図-10(a) (e)はそれぞれ初期乾燥密度 $\rho_{\mathrm{d} 0}=1.15,1.20$, $1.25,1.30,1.35 \mathrm{Mg} / \mathrm{m}^{3}$ における不飽和地盤を加振した際 の飽和度〜加速度関係を初期乾燥密度 $\rho_{\mathrm{d} 0}$ ごとに示す. ○のプロットは振動数一定 $(5 \mathrm{~Hz}), \times$ のプロットは振 幅一定 $(10 \mathrm{~mm})$ ，塗りつぶしのプロットは大型土槽を 振動数一定で加振した結果を示寸.



(a) $\rho_{\mathrm{d} 0}=1.15 \mathrm{Mg} / \mathrm{m}^{3}$

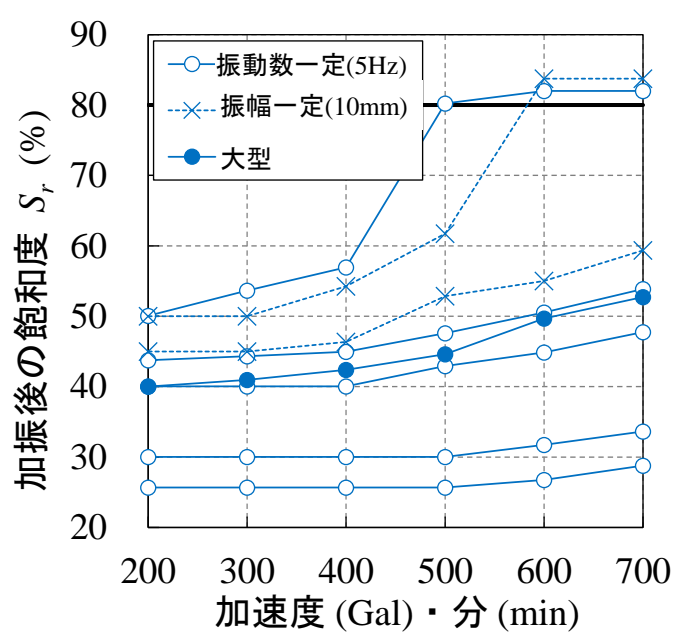

(b) $\rho_{\mathrm{d} 0}=1.20 \mathrm{Mg}^{3} \mathrm{~m}^{3}$

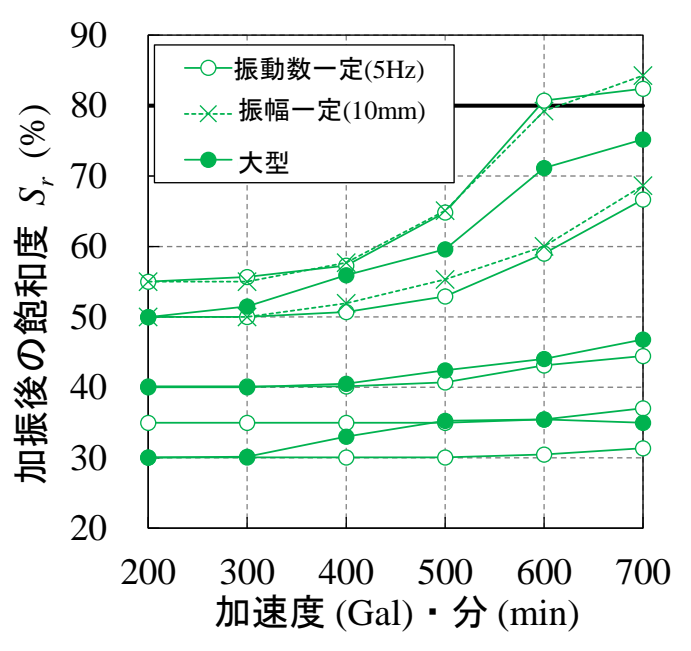

(c) $\rho_{\mathrm{d} 0}=1.25 \mathrm{Mg} / \mathrm{m}^{3}$

図-10 加振後の飽和度〜加速度関係 


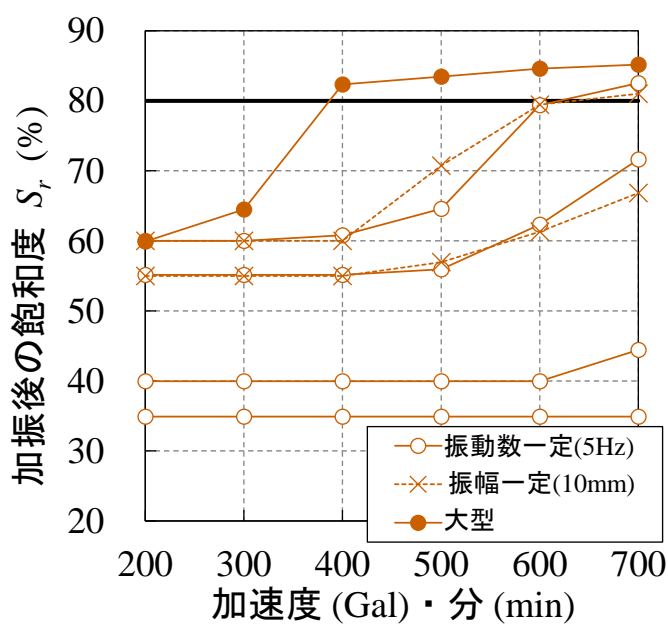

(d) $\rho_{\mathrm{d} 0}=1.30 \mathrm{Mg} / \mathrm{m}^{3}$

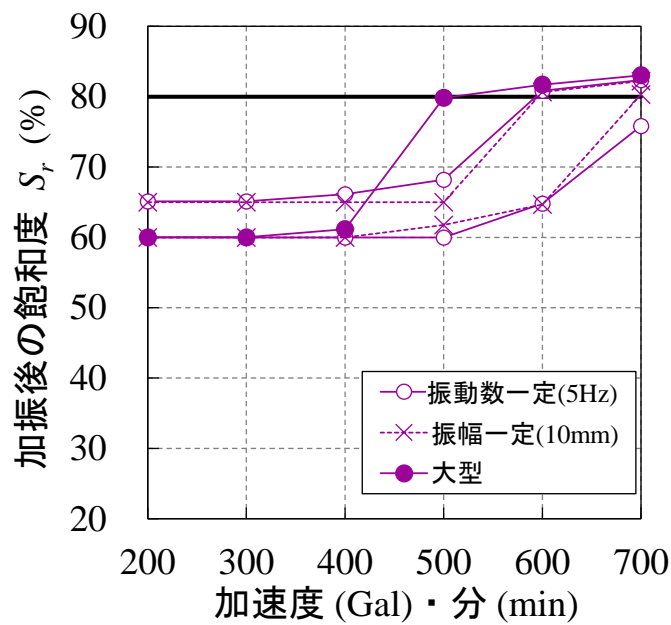

(e) $\rho_{\mathrm{d} 0}=1.35 \mathrm{Mg} / \mathrm{m}^{3}$

図-10 (つづき)

図-10(a) (e)より，加速度が大きくなるほど 1 分間の 加振による飽和度の上昇は大きくなることがわかる。一 方，飽和度が $80 \%$ を超えると飽和度が上がりにくくなる ことがわかる.

なお，加振により飽和度が $80 \%$ 以上になる 11 ケース ではいずれも地表面に流出水が発生（不飽和液状化）し た．逆に，加振後の飽和度が $80 \%$ 以下のケースではいず れも不飽和クラックを示した。

図-10(a) (e)において，初期条件（初期飽和度と初期 乾燥密度）が同じ場合の小型土槽と大型土槽の加振後の 飽和度〜加速度 - 分関係を比較すると，加振に伴う飽和 度の上昇はいずれのケースにおいても大型土槽のほうが 小型土槽より早かった。不飽和液状化をもたらすエネル ギーは大型土槽の方が小型土槽より小さいことを示して いる. 大型土槽と小型土槽では模型高さが 2 倍以上大き いため，深度方向の飽和度分布や境界条件の影響が無視

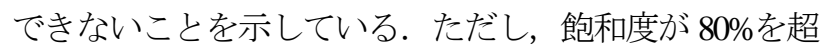

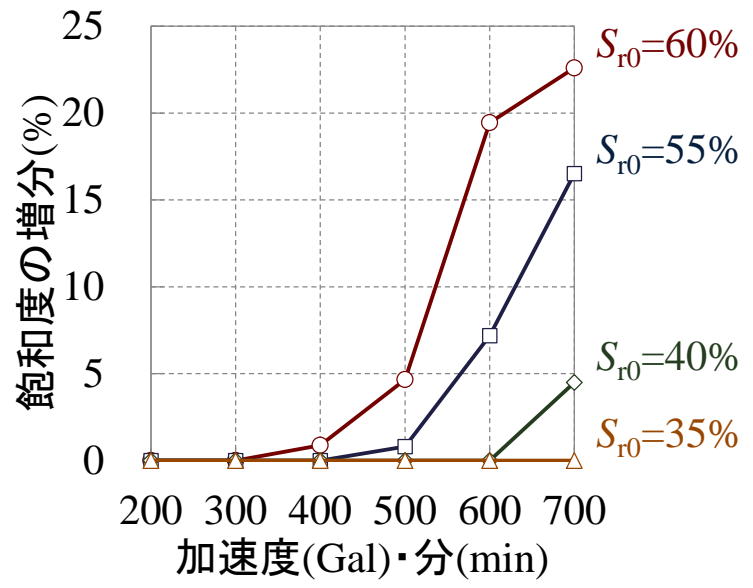

図-11 飽和度増分 加速度関係 $\left(\rho_{\mathrm{d} 0}=1.30 \mathrm{Mg} / \mathrm{m}^{3}\right)$

え，不飽和液状化を示した後の飽和度は上昇しにくくな ることから，不飽和液状化後においては飽和度分布は一 様に近づくと考えられる，言い換えると，不飽和クラッ ク時は飽和度が不均質に分布していると考えられる. 今 後, 深度方向に土中水分計等を設置して実験を行うなど, 深度方向〜飽和度関係の詳細な分析が必要である.

図-11 は, 初期乾燥密度 $\rho_{\mathrm{d} 0}=1.30 \mathrm{Mg} / \mathrm{m}^{3}$ において, 初 期飽和度を変化させた場合における, 加振後の飽和度 $S_{\mathrm{lf}}$ から初期飽和度 $S_{\mathrm{l} 0}$ を減じた飽和度増分 $\left(\Delta S_{\mathrm{r}}=S_{\mathrm{ff}}-S_{\mathrm{l}}\right)$ ～加速度関係を示している. 図-11 から初期飽和度が大 きいほど, 加振後の飽和度増分が上昇しやすく（小さな 加速度でも飽和度増分が発生しや寸い，加速度が大き くなった際の加振による飽和度の上がり方が大きいとわ かる.

\section{5. 鹿島海浜砂の破壊形態の飽和度による評価の 試み}

鹿島海浜砂の破壊形態を，土槽の形状・サイズによら ず相対的に評価する手法を考える.

図-12 に, 700 gal 加振後の飽和度〜初期飽和度関係を 表したグラフを示す．白抜きのプロットが小型土槽，塗 りつぶしのプロットが大型土槽での実験結果をそれぞれ 示寸. 対角線は加振後の飽和度が初期飽和度と等しい状 態，つまり，体積変化を起こさないラインを示し，この ラインより上側は圧縮，ラインより下側は膨張をそれぞ れ示す．今回の実験のケースではすべて圧縮（沈下）を 示した.

ここで, 初期飽和度 $S_{10}$ と初期乾燥密度 $\rho_{\mathrm{d} 0}$ から加振後 の飽和度 $S_{\mathrm{ff}}$ を評価する第一段階の試みとして， $S_{\mathrm{ff}}$ が $S_{10}$ の線形関数として与えられる次式を考える. 


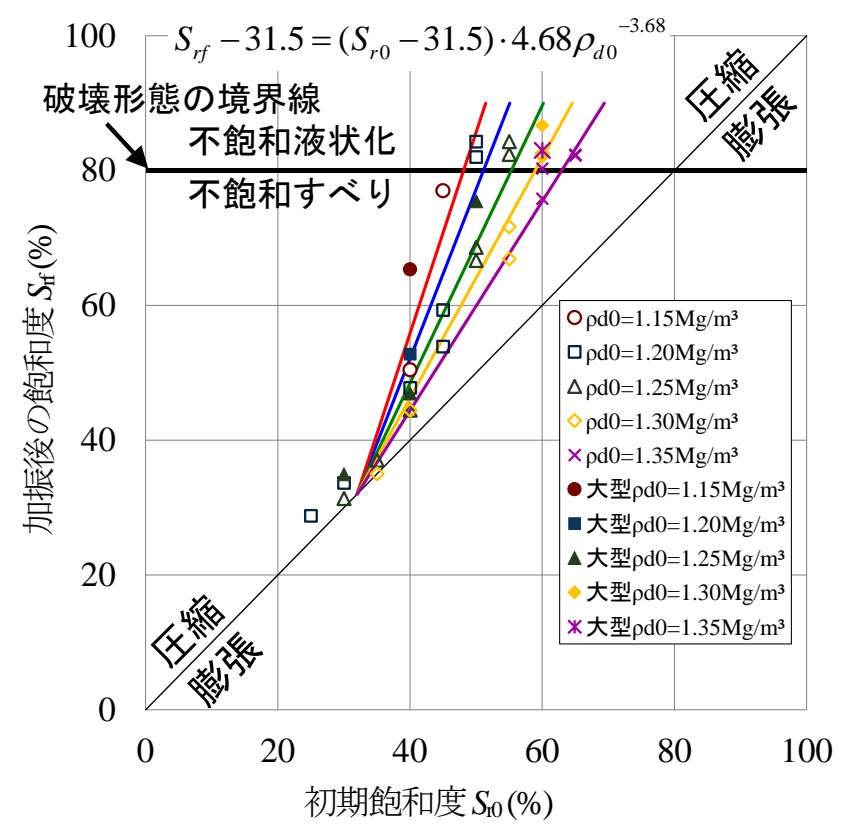

図-12 加振後の飽和度～初期飽和度関係

$$
S_{r f}-S_{r \alpha}=A \cdot\left(S_{r 0}-S_{r \alpha}\right) \cdot \rho_{d 0}^{-B}
$$

$\left(S_{r \alpha}, A, B, \quad\right.$ : 実験定数（フィッティングパラメー タ，図-12では $\left.\left.S_{r \alpha}=31.5(\%), A=4.68, B=3.68\right)\right)$

ただし，式中のパラメータ $A$ は，加振条件や境界条 件（土槽サイズなど）によって変化すると考えられたい 式(1)より得られた直線を図-12 に示す. 本研究で行っ た実験結果は小型土槽，大型土槽ともにこの直線上に概 ね一致している，土槽サイズを小さくしていけば，より 土要素としての挙動を規定できると考える. 小型土槽, 大型土槽ともに初期飽和度 40\%程度までは初期飽和度と 加振後の飽和度の差があまりみられない．飽和度の上昇 率は初期乾燥密度が小さいほど大きく, 初期乾燥密度の 違いで概ね線形的に関連づけられることが確認できる. よって，式(1)は 200～700Gal の加振条件において加振後 の飽和度〜初期飽和度関係を概ね評価するための一手法 と考える.これらの結果は，地盤内において飽和度の不 均質な分布は存在していると考えられるが，地震外力に 伴う飽和度変化と破壊形態を初期乾燥密度，初期飽和度 から概ね評価できる可能性を示している．同じサクショ ンでも乾燥密度（あるいは間隙比）や，ヒステリシス （吸水過程か排水過程か）によって飽和度は異なるので 飽和度についてはある程度幅を持たせて考えておくほう がよいとおもわれる.

図-12 において, 初期乾燥密度 $1.30 \mathrm{Mg} / \mathrm{m}^{3}$, 初期飽和 度 $35 \%$ ケースを除き，すべてのケースで地盤にクラッ クが発生（不飽和クラック）した。 一方，加振後の飽和 度が 80\%以上の 6つのケースでは小型土槽, 大型土槽に 関わらずいずれも地表面に流出水が発生（不飽和液状化）
した. 逆に，加振後の飽和度が $80 \%$ 以下では不飽和液状 化を示さなかった。このことから，飽和 $80 \%$ 付近を境界 として加振時破壊形態が不飽和クラックから不飽和液状 化へと転移すると考えられる. このような加振時の不飽 和土の破壊形態の転移に関する研究事例は見当たらない が，そのメカニズムについて以下に考察を述べる.

本試験中では，含水比が一定の試験であり，模型地盤 の沈下は空気の排出（排気）（または圧縮）によって生 じていると考えることができる，議論を簡単にするため に，ここでは空気の圧縮を考えず，全て排気によって沈 下しているものとする.ささて，絶乾状態でなければ，土 粒子は吸着水と毛管水（サクションによる毛管現象で保 持される水) で覆われているが，加振に伴い一時的に間 隙水圧が上昇（サクションが減少）すると，毛管水の一 部が自由水へと転移する。この毛管水の減少により土骨 格が圧縮する．併せて自由水と空気の置換が起こり，排 気が生じる. 圧縮と排気により加振後は飽和度が上昇す る. 初期飽和度が高いほど変形しやいのは, 自由水が相 対的に多くなることに関係していると考えられる. 加振 後の飽和度の上昇は, サクションの低下を意味し，不飽 和土の有効灾力の減少を意味している. 加振に伴うせん 断時の土粒子の移動（すべり）が連続的に可視化できる サイズまで発達したものが不飽和クラックとなっている と考えられる. 不飽和クラック後も加振を続けると, 飽 和度は上昇し続ける，ただし，突固めによる締固め試験

(吸水過程) では飽和度の最大值が $80 \%$ 程度で，水平浸 潤過程（吸水過程）での給水部付近の飽和度が $80 \%$ 程度， 水分特性曲線（排水過程）におけるサクション $0 \mathrm{kPa} の$ 飽和度は $90 \%$ 弱である. 上昇する飽和度には限界值があ ると考えるほうが自然である. サクションが 0 であれば 地表面の不飽和土の有効応力は 0 である。 また，毛管水 が 0 であり，自由水へと全てが転移していることを意味 する. 不飽和土の有効応力が 0 の状態を不飽和液状化と すれば，地表面においてはサクションが０のときの飽和 度から $100 \%$ までの飽和度の領域が不飽和液状化に該当 すると考えられる. そして，サクションの消失により毛 管水が自由水へと転移することが破壊形態の転移につな がっていると考える. 一方，深度方向の検討については サクション分布と飽和度分布などを合わせて検討してい く必要がある. 今後, 土中水分計やテンシオメータ-な どの設置を行い，データの蓄積とともにメカニズム解明 に向けた詳細な分析が必要である.

\section{6. おわりに}

振動台を用いて鹿島海浜砂から成る不飽和模型地盤 (地下水位が無い地盤) の地震時の沈下挙動・破壊形態 
を実験的に考察した. その結果，初期飽和度が大きいほ ど地震時の飽和度は増加しやすいことがわかった。 しか し，飽和度 80\%を境にして飽和度増分が著しく減少する 傾向がみられた. 加振により沈下が生じた結果, クラッ クや寸べり破壊を示した地盤で，土槽全体の飽和度は 80\%未満であり，液状化した地盤は 80〜83\%であった. このことから，不飽和地盤の破壊形態について，ある飽 和度を境界にして相転移が起こると考えた。また，初期 飽和度が小さい場合, $700 \mathrm{gal}$ ま加振しても破壞しなか った，逆に言えば不飽和地盤が破壊するか否かは，地震 前の飽和度を把握すれば判断できると考える.

不飽和模型地盤の浸潤・締固め特性と加振時破壊形態 を実験的に考察した. その結果，浸潤試験における最大 の飽和度, 締固め曲線の漸近寸る飽和度, 加振時破壊形 態に相転移が生じる飽和度が概ね $80 \%$ であった．また， 飽和度が 80\%を超えると加振しても飽和度が上がりにく くなった.このことから不飽和地盤の浸潤・締固め特性 と加振時破壊形態の関連性が示唆される.

今後, 不飽和地盤の地震時破壊挙動に関する研究の加 速的な発展に向け, 本研究成果を周知していきたい.

謝辞 : 本研究の一部は国土交通省の河川砂防技術研究開 発助成 地域課題分野（砂防）（代表者: 荒木功平）, 国立大学法人山梨大学の分野横断的融合研究プロジェク 卜（代表者：鈴木猛康）の援助を受けました.ここに深 甚の謝意を表します。また，北爪貴史氏（株式会社東電 設計）, 森智昭氏（甲府市），後藤聡氏（国立大学法人 山梨大学）に多くのご助言・ご協力をいただきました. ここに深甚の謝意を表します。

\section{参考文献}

1) 竹村弥生, 建山和由 : 振動場における粒状体の挙動に関 する実験的研究, 土木学会論文集 C, Vol.68, No.1, pp127-137, 2012.

2) Sakai, T., Suehiro, T., Tani, T. and Sato, H.: Geotechnical performance of the Kashiwazaki-Kariwa Nuclear Power Station caused by the 2007 Niigataken Chuetsu-oki earthquake, Case History Volume for Performance-Based Design in Earthquake Geotechnical Engineering, Technical Committee No.4, ISSMGE, pp.1-29, 2009.

3) 若松加寿江, 吉田望, 清田隆 : 土木学会東日本大震 災被害調査団（地震工学委員会）緊急地震被害調查 報告書，第 6 章造成地の被害，p.7，2011.

4) 日経アーキテクチュア：「地震で不同沈下」通らず 積水敗訴，卜ピックス，2016-10-22， http://kenplatz.nikkeibp.co.jp/atcl/bldhbd/15/1611/101400 001/（2016年 10 月 28 日閲覧）

5) 北爪貴史, 酒井俊郎, 佐藤博, 佐藤正行 : 繰返しせ ん断による不飽和砂質土の体積収縮特性と沈下量推 定に関する基礎的検討, 土木学会論文集 C（地圈工 学) , Vol.68, No.2, pp.410-421, 2012.

6) 河井正, 石丸真, 佐藤博, 末広俊夫, 谷智之: 剛な 構造物近傍地盤の地震時沈下挙動に関する $1 \mathrm{G}$ 場模 型振動台実験（その 1) 変形メカニズムについて, 土木学会第 63 回年次学術講演会, pp.93-94, 2008.

7) 細谷旭弘, 顧琳林, 張鋒 : 低・中拘束圧で繰返し載 荷を受ける豊浦砂の力学特性に関する実験的研究, 第 50 回地盤工学研究発表会, pp.455-456, 2015.

8）社団法人 地盤工学会 : 土質試験一基本と手引一 （第二回改訂版），pp.17-25，2011.

9) 荒木功平, 村山啓太, 安福規之, 大嶺聖, ハザリカ ヘマンタ：粒度分布を反映した赤土等の土砂流出量 算出のモデル化に関する研究, 第 9 回環境地盤工学 シンポジウム論文集, pp.213-216, 2011.

10) 神谷浩二, Rully BAKRIE, 本城勇介: 保水性を制御 した不飽和土の透気係数の測定, 土木学会論文集 C, Vol.62, No.3, pp.679-688, 2006.

11) 気象庁ウェブページ: 気象庁強震波形, http://www.data.jma.go.jp/svd/eqev/data/kyoshin/jishin/in dex.html, 2015.

(2016.11.2受付, 2017.1.5 修正, 2017.1.18 受理)

\section{AN EXPERIMENTAL CONSIDERATION ON PERMEABILITY, COMPACTION CHARACTERISTIC AND FAILURE PATTERN BY VIBRATION FOR UNSATURATED SOILS}

\section{Hiroaki FUJIMORI and Kohei ARAKI}

In recent years, unsaturated backfill that groundwater level is in a deep position, result in different settlement from the behavior of the saturated ground, it has been frequently reported. However less research for settlement of unsaturated soil by seismic motion, the mechanism has not been elucidated. In this study, the relationships between the amount of settlement, degree of saturation and dry density have been assessed, to prepare a unsaturated model ground, by using a shaking table. It was confirmed two failure pattern for the unsaturated ground liquefaction and cracks. The possible is found the boundary value of the degree of saturation. 